\title{
POSTOPERATIVE SORE THROAT: INFLUENCE OF TRACHEAL TUBE LUBRICATION VERSUS CUFF DESIGN
}

\author{
Edward A. Loeser, Theodore H. Stanley, William Jordan and Richard Machin
}

\begin{abstract}
The incidence and severity of postoperative sore throat was evaluated in six groups of 20 patients each after elective orthopedic surgery. Groups I to $V$ had tracheal intubation with Portex dispasable polyvinylchloride tracheal tubes and group VI had mask anaesthesia. All groups were expos ed to heated humidified gases. Tracheal tubes in groups I-III were uncuffed and lubricated with four per cent lidocaine jelly (group I), four per cent lidocaine hydrochloride anaesthetic solution (group II) or normal saline (group III). Patients in group IV had unlubricated tubes with large residual volume cuffs, patients in group $V$ unlubricated tubes with small residual volume cuffs and patients in group VI (mask anaesthesia) had the lowest incidence and severity of postoperative sore throat while those in group I had the highest incidence and most severe postoperative sore throats. Patients in group $V$ had a lower incidence and severity of postoperative sore throat than patients in all other groups, excepl group VI. Postoperative sore throat was equally common and severe in patients in groups II. III, and IV. The data indicate that, with the use of heated humidified gases. tracheal intubation with either cuffed or uncuffed tubes produces a greater incidence and severity of postoperative sore throat than mask anaesthesia. In addition, our findings suggest that lubrication of tracheal tubes provides no advantage in terms of reducing postoperative sore throat and. depending on the lubricant, can increase the incidence and severity. Finally, our results demonstrate that the tracheal tube causing the least incidence and severity of postoperative sore throat is one with an unlubricated low residual volume cuff.
\end{abstract}

A NUMBER OF RECENT STUdies have shown that trachcal tube conformity as well as cuff-trachea contact area have important effects on the incidence and severity of postoperative sore throat following intubation with modern disposable polyvinylchloride tracheal tubes. ${ }^{1-3}$ Investigations some years ago with reusable latex rubber tracheal tubes indicated that lubrication could influence postoperative sore throat. ${ }^{4-6}$ This study was undertaken to evaluate the incidence and severity of postoperative sore throat with modern disposable polyvinyl tracheal tubes, lubricated and unlubricated, with and without cuffs.

\section{Methods}

Postoperative sore throat was evaluated in 120 patients who had undergone orthopaedic opera-

Edward A. Laeser, M.D., Clinical Instructor in Anesthesiology; Theodore H. Stanley, M.D., Professor of Anesthesiology/Surgery: William Jordan, M.D., Associate Professor of Anesthesiology; Richard Machin, D.D.S., Resident in Anesthesiology. The Department of Anesthesiology. University of Utah College of Medicine, Salt Lake City, Utah, 84132, U.S.A. Address reprint requests to Dr. Edward A. Loeser. tions on an extremity. All were in the supine position. Five groups of 20 patients each had tracheal intubation with 7.5 to $8.5 \mathrm{~mm}$ (inside diameter) cuffed or uncuffed Portex tracheal tubes. Twenty additional patients (group VI) were subjected to similar operations but without tracheal intubation. Tracheal tubes used in patients of groups I-III were uncuffed but lubricated. Tubes in group I were lubricated with four per cent lidocaine jelly while those in groups II and III were lubricated with four per cent lidocaine hydrochloride anaesthetic solution and normal saline, respectively. Tracheal tubes in patients in group IV and V were cuffed but unlubricated. Tubes in group IV had low-pressure high residual volume cuffs and those in group $V$ high pressure low residual volume cuffs.

Patient selection into one of the six groups was done randomly on the evening before operation. All patients were similarly premedicated. Anaesthesia was induced with thiopentone $3-4 \mathrm{mg} \cdot \mathrm{kg}^{-1}$ and maintained with halothane 1 to 2 percent and nitrous oxide 60 per cent in oxygen, using a heated humidified semi-closed circuit. Temperature at the tracheal tube was between $35^{\circ} \mathrm{C}$ and $37^{\circ} \mathrm{C}$. A Bird ventilator was used with 
TABLE I

Mean Incidence and Severity $(0-3 \pm$ SD) Postoperative Sore Throat

\begin{tabular}{lllll}
\hline \hline Group & \multicolumn{1}{c}{ Tube } & \multicolumn{1}{c}{ Lubricant } & $\begin{array}{c}\text { Incidence } \\
(\%)\end{array}$ & $\begin{array}{c}\text { Severity } \\
(0-3)\end{array}$ \\
\hline I & Uncuffed & $4 \%$ lidocaine jelly & $90^{*}$ & $2.10 \pm 0.8^{*}$ \\
II & Uncuffed & $4 \%$ lidocaine solution & 40 & $0.45 \pm 0.6$ \\
III & Uncuffed & Saline solution & 40 & $0.40 \pm 0.4$ \\
IV & Large volume cuff & none & 46 & $0.49 \pm 0.6$ \\
V & Low volume cuff & none & $25 \ddagger$ & $0.31 \pm 0.4$ \\
VI & None (mask) & none & $15 \dagger$ & $0.20 \pm 0.3$ \\
\hline
\end{tabular}

$* \mathbf{P}<0.001$ as compared with all other groups utilizing the Chi square test

$\uparrow P<0.01$ as compared with all other groups utilizing the Chi square test.

$\ddagger \mathrm{P}<0.05$ as compared with all other groups utilizing the Chi square test.

the vaporiser in circle. Following administration of succinylcholine $1.5 \mathrm{mg} \cdot \mathrm{kg}^{-1}$. (groups I-V) the tracheae were intubated atraumatically in the usual fashion with the use of a stylet. During laryngoscopy in groups I-III an attempt was made to evaluate the laryngeal-tracheal size so that a tracheal tube could be chosen that would be large enough to prevent all but a minimum of air leak during positive pressure breathing. Cuffs on tubes in patients in groups IV and $V$ were filled with a sample of the inspired mixture of gases until the trachea was just sealed. All patients had sterile, disposable, Ohio plastic oral airways (size 3 or 4) in place throughout the operation and some had them in place during the early postoperative period. Following recovery from succinylcholine, patients were allowed to breathe spontaneously but, on occasion. respirations were assisted.

\section{RESULTS}

Duration of operation and intubation, types of procedures, age, weight and sex distributions were similar in all groups of patients studied. Patients who were not intubated (group V1) had a postoperative sore throat incidence and severity index of 15 per cent and 0.20 , respectively. These figures were significantly smaller than for all other groups (Table I). The incidence and severity of postoperative sore throat was significantly greater $(P<0.001)$ in group I (uncuffed tube lubricated with four per cent lidocaine jelly) than in all other groups. Patients in group V (low residual volume unlubricated cuff) had a lower incidence and severity of postoperative sore throat than patients in all other groups except group VI. The incidence and severity of postoperative sore throat was similar in patients in group II (un- cuffed tubes lubricated with saline) and IV (large residual volume unlubricated cuff).

\section{Discussion}

The results of this study indicate that tracheal intubation with either cuffed or uncuffed disposable polyvinylchloride tubes produces a greater incidence and severity of postoperative sore throat than does mask anaesthesia when employing heated humidified anaesthetic gases in semi-closed circle system. The data suggest that lubricants on uncuffed tubes provide no advantage and, as in the case of four per cent lidocaine jelly, may be a disadvantage in terms of sore throat after operation. Finally, our findings demonstrate that unlubricated low residual volume cuffs are associated with a lower incidence and severity of postoperative sore throat than unlubricated high residual volume cuffs or uncuffed tracheal tubes irrespective of lubrication.

It is not unexpected that mask anaesthesia utilizing warm humidified anaesthetic gases should be less traumatic in terms of the development of sore throat postoperatively than endotracheal anaesthesia. Similarly, it was not unexpected that patients in group $V$ would have a lower incidence and magnitude of postoperative sore throat than patients in group IV, in view of previous reports from this laboratory indicating that large volume cuffs produce a larger area of damage to tracheal mucosa and a higher incidence of sore throat than small volume cuffs in circuits utilizing non-humidified gases, ${ }^{2,3,7}$ What was unexpected was the remarkably high incidence and severity of postoperative sore throat in patients whose tracheae had been intubated with uncuffed tubes lubricated with four per cent lidocaine jelly. Since patients in group II had four 
per cent lidocaine anaesthetic solution as a lubricant and sustained less than half the incidence and severity of sore throat found in patients of group I, our findings suggest that the jelly or preservatives in the jelly (polyethylene glycol and propylene glycol) is irritating or damaging to $\mathrm{mu}$ cosa of the trachea or upper airway.

Another unexpected finding in this study was the lower incidence and severity of postoperative sore throat in patients in group $V$ compared to any of the groups with uncuffed tubes. Our data do not allow an easy explanation of this finding. However, it is possible that air leaks created during spontaneous respiration in patients with uncuffed tracheal tubes allow air with less than 100 per cent humidity to be drawn past upper airway mucosa, causing some dehydration and damage to these cells. Whether such changes do occur and are the explanation for the differences observed between group V and groups II and III will have to be determined by additional studies.

\section{SUMMARY}

Our findings in this study demonstrate that mask anaesthesia results in less postoperative sore throat, when utilizing heated humidified gases in a semi-closed circle system, than does anaesthesia with a tracheal tube. In addition, the data indicate that uncuffed tubes provide no ad- vantage over cuffed tubes in terms of the development of sore throat after operation, and cause an extremely high incidence of sore throat when lubricated with four per cent lidocaine jelly.

\section{REFERENCES}

1. Lundholm, C. \& Carroll. R.G. Evaluation of tube deformation pressure in vitro, Crit. Care Med. 3: 196 (1975).

2. Loeser, E.A., Orr, D.L. Bennett, G.M. \& STANLEY, T.H. Endotracheal tube cuff design and postoperative sore throat. Anesthesiology 45: 684 (1976).

3. Loeser, E.A., Machin, R., Colley, J., Orr, D., Bennett, G.M. \& Stanley, T.H. Postoperative sore throat-importance of endotracheal tube conformity versus cuff design. Anesthesiology 49: 430 (1978).

4. Hartsell. C.J. \& Stephen, C.R. Incidence of sore throate following endotracheal intubation. Canad. Anaes. Soc. J. 11: 307 (1964).

5. LUND, L.O. \& DaOS, F.G. Effects on postoperative sore throat of two analgesic agents and lubricants used with endotracheal tubes. Ancsthesiology 26: 681 (1965).

6. WinKel, E. \& KNUdSEN. J. Effects on the incidence of postoperative sore throat of 1 per cent cinchocaine jelly for endotracheal intubation. Anesth. Analg. 50: 92 (1971).

7. Loeser, E.A., Hodgs, M., Gleidman, J. StanLEY, T.H., JOhansen, R.K. \& Yonetani, D. Tracheal pathology following short-term intubation with low and high pressure endotracheal tube cuffs. Anesth. Analg. 57: 577 (1978).

\section{RÉSUMÉ}

On a évalué la fréquence et la gravité des maux de gorge après une intervention orthopédique non urgente sur six groupes de 20 patients. Pour les groupes de là V, on a utilisé des canules trachéales Portex jetables en chlorure de polyvinyle et une anesthésie au masque a été réalisée pour le groupe VI. Dans tous les cas, on a eu recours à une humidification chauffée. Les canules des groupes I à 111 ne portaient pas de ballonnet gonflable et furent lubrifiées avec de la gelée de lidocaine quatre pour cent (groupe 1), de la solution d'hydrochlorure de lidocaine quatre pour cent (groupe II), ou du soluté physiologique (groupe III).

On a utilisé des canules non lubrifićes avec ballonnet à petit volume résiduel pour le groupe [V, et des canules à grand volume résiduel pour le groupe V. C'est le groupe VI (anesthésié au masque) qui a présenté les maux de gorge les moins graves et les moins fréquents, alors que f'incidence et la sévérité en étaient les plus élevées dans le groupe I. A près le groupe VI, c'est dans le groupe $V$ que les meillcurs résultats ont été obtenus. Les maux de gorge ont été de fréquence et de gravité identiques dans les groupes II, III et IV.

Ces données montrent qu'avec l'emploi de gaz humidifiées et chauffés. I'intubation trachéale avec des canules à ballonnet ou sans ballonnet cause des maux de gorge plus fréquents et plus graves que l'anesthésie au masque. De plus, ces résultats semblent indiquer que la lubrification des canules trachéales ne prévient pas les maux de gorge et peut mème en augmenter la fréquence et la sévérité selon la substance employée. Finalement, les résultats de cette étude montrent que la canule non lubrifiée et à volume résiduel faible est celle qui cause le moins de problèmes. 